\title{
KUALITAS HASIL PENERJEMAHAN KELOMPOK MAHASISWA S2 UNM-MALANG \\ (Studi Kasus Hasil Penerjemahan Buku Teks \\ "Approaches to Discourse" oleh Deborah Schiffrin)
}

\author{
Agus Supriyadi \\ Jurusan Pendidikan Bahasa dan Seni FKIP Universitas Khairun \\ agsbakin78@gmail.com
}

\begin{abstract}
ABSTRAK
Penelitian ini bertujuan untuk mengetahui kualitas terjemahan dari bahasa Inggris ke dalam bahasa Indonesia. Penelitian ini menggunakan pendekatan deskriptif kualitatif. Data diperoleh melalui pengamatan dan content analysis melalui teknik catat. Data yang diperoleh dianalisis dengan menggunakan teknik analisis interaktif. Hasil penelitian menunjukan bahwa penilaian kualitas terjemahan terhadap naskah Buku Teks dari bahasa sumber ke bahasa sasaran menghasilkan sebuah evaluasi karya terjemahan secara komprehensif atau holistik sehingga secara keseluruhan dapat disimpulkan bahwa kualitasnya masih dibawah standar. Artinya belum memenuhi aspek keakuratan, keberterimaan dan keterbacaan secara memadai.
\end{abstract}

Kata Kunci: penilaian kualitas terjemahan, bahasa Inggris, Bahasa Indonesia

\section{A. PENDAHULUAN}

Permasalahan utama dalam penerjemahan adalah kesepadanan antara teks bahasa sumber (BSu) dan teks bahasa sasaran (BSa). Terkait dengan perihal kesepadanan yang ditetapkan sebagai suatu kata kunci, Catford mendefinisikan penerjemahan sebagai penempatan (replacement) teks bahasa sumber dengan teks yang sepadan dalam bahasa sasaran. The replacement of textual material in one language (SL) by equivalent textual material in another language (TL) and the term equivalent is a clearly a key term (Catford, 1965:20-21). Meskipun sangat jarang terdapat padanan 
suatu kata dalam bahasa sumber yang sama dengan arti dalam bahasa sasaran, namun keduanya dapat berfungsi secara sepadan pada saat keduanya dapat saling dipertukarkan (interchangeable). Dibalik itu, namun Penerjemahan bukanlah suatu hal yang sederhana, melainkan sesuatu yang dapat dikategorikan sebagai sesuatu yang kompleks. Disebut kompleks karena penerjemahan tidak terlepas dari berbagai faktor lain yang terkait dengan linguistik, seperti faktor budaya misalnya. Hatim menyatakan A translation work is a multi-faceted activity; it is not a simple matter of vocabulary and grammar only but that it can never be separated from the culture (Hatim, 2001:10).

Oleh karena itu, banyak orang mengatakan bahwa tidak ada pekerjaan yang lebih sulit dibandingkan dengan pekerjaan menerjemahan. Penerjemah tidak hanya harus menguasai bahasa sumber (BSu) nya dengan baik; tetapi mereka juga harus memiliki kemampuan pemahaman menyeluruh tentang bidang pengetahuan yang dicakupi teks BSu tersebut. Artinya, setiap konotasi sosial, kultural, dan emosional yang perlu dicantumkan dalam bahasa sasaran (BSa) harus dipahami benar. Kesadaran tertentu yang sama perlu dihadirkan untuk BSa, sehingga halhal yang berkaitan dengan penyusunan kata-kata dan frasa tertentu, ungkapan-ungkapan tabu, ekspektasi lokal, dan sebagainya dapat diperhitungkan dengan matang karena menerjemahkan tidak hanya sekadar mentransfer atau merubah BSu ke BSa, akan tetapi lebih dari itu.

Terlepas dari perbedaan-perbedaan cara untuk menemukan kesepadanan dalam proses penerjemahan diperlukan suatu pendekatan, metode, dan teknik. Emzir mengatakan bahwa pendekatan dalam bidang penerjemahan berhubungan dengan prinsip-prinsip teoretis tentang penerjemahan, metode berhubungan dengan langkah procedural dalam proses penerjemahan, sementara teknik adalah strategi yang digunakan 
oleh penerjemah untuk mengatasi kesulitan-kesulitan yang dihadapi dalam memeroleh kesepadanan dalam penerjemahan (Emzir, 2015: 55-56).

Catford menyatakan penerjemahan merupakan kegiatan penggantian materi tekstual dalam suatu bahasa sebagai bahasa sumber (Bsu) dengan materi tekstual yang sepadan (equivalent) dalam bahasa sasaran (Bsa). Catford menganggap penerjemahan mengarah pada upaya penggantian teks atau bentuk semata. Sementara, teks suatu bahasa tidak dapat dialihkan begitu saja tanpa menangkap maksud pesan yang ada dibalik ungkapan tertentu, bahkan teks yang sepadan bisa saja maknanya berbeda (Catford, 1980:20).

Seperti pendapat Mounin dalam Newmark -translation cannot simply reproduce, or be, the original" berarti proses penerjemahan tidak dapat dianggap semata-mata menyampaikan ulang dan mempertahankan bentuk asli semata dari teks sumber, namun banyak aspek yang harus dipertimbangkan penerjemah untuk mencapai kesepadanan (Newmark, 1988:3) .

Melengkapi definisi di atas, Bassnett-McGuire menyatakan bahwa penerjemahan merupakan usaha menyampaikan sebuah teks dalam Bsu ke dalam Bsa, dengan mengupayakan (1) makna lahir dari kedua teks sama dan (2) struktur dari Bsu juga sedapat mungkin dipertahankan, namun tidak begitu dekat untuk menghindari penyimpangan serius pada struktur bahasa sasaran. Berdasarkan definisi di atas, Bassnett-McGuire melengkapi definisi Catford sehingga penerjemahan tidak lagi dipandang sebagai kegiatan mengganti teks Bsu dengan teks yang ekuivalen dalam Bsa semata, namun perlu dipertimbangkan juga aspek makna dan struktur kalimat dari teks sumber sedapat mungkin sama (Bassnett, 1991:2).

Namun, jika dicermati definisi ini pun masih terfokus pada bentuk (text/form) dan walaupun secara tersirat Bassnett-McGuire sebenarnya telah menyadari adanya perbedaan struktur yang terdapat diantara kedua 
bahasa, bahkan mempertahankan struktur yang sama persis dengan Bsu malah dapat menyebabkan distorsi makna. Sehingga terlihat keraguannya dalam menganjurkan mempertahankan struktur Bsa, tetapi ia pun belum memiliki ukuran sejauh mana struktur tersebut harus dipertahankan. Berbeda dengan kedua definisi di atas, Savory menyatakan penerjemahan dimungkinkan dengan usaha pemadanan pikiran [pesan] yang tersirat dibalik tuturan verbal yang berbeda. Dari pandangan Savory, terlihat bahwa penerjemahan sebenarnya kegiatan yang mengusahakan pengalihan pesan yang terdapat dibalik ungkapan, bukan hanya mengalihkan ungkapan tersebut. Tuturan verbal di sini mengacu pada bahasa dalam ragam tulis dan lisan (Savory, 1969:13).

Selain perbedaan mendasar bahwa yang dialihkan itu pada hakikatnya pesan bukan materi tekstual, dari beberapa definisi yang ajukan para ahli juga memiliki perbedaan dari segi media dan produk yang dihasilkan. Dari sudut pandang Catford (1980) dan Bassnett-McGuire (1991) mereka membatasi bahwa yang dimaksud penerjemahan hanya berupa pengalihan teks dalam Bsu yang dilakukan secara tertulis sehingga produknya juga berupa teks. Sementara, Pinchuck menyatakan penerjemahan sebagai $\|$... a process of finding a $T L$ equivalent for an $S L$ utterancell. Istilah "utterance" (ujaran atau tuturan) mengindikasikan bahwa penerjemahan juga dapat dipahami sebagai proses pengalihan pesan lisan dengan media lisan. Pada pelaksanaannya, penerjemahan (translation) memang tidak hanya dilakukan secara tulis atau lisan saja (Pinchuck, 1977:38).

Kridalaksana (2008:181), Bell (1991:12-13), dan Nida \& Taber (1982:12) menyatakan penerjemahan itu adalah pengalihan amanat atau mereproduksi suatu pesan dari Bsu ke dalam Bsa (antarbudaya dan/atau antarbahasa) dalam tataran gramatikal atau leksikal dengan makna atau kandungan isi (maksud), efek, ujud, dan gaya bahasanya sedapat mungkin 
dipertahankan. Di sini, dengan lebih lengkap Kridalaksana (2008), Bell (1991), dan Nida \& Taber (1982) menyatakan bahwa penerjemahan itu: (1) pengalihan pesan/amanat (content) dari Bsu ke Bsa (antarbahasa) dalam bentuk tulis maupun lisan, karena pesan dapat saja dalam bentuk tertulis ataupun lisan, (2) hal utama yang harus diingat bahwa kesepadanan pesan antara Bsa dan Bsu merupakan prioritas utama, (3) kemudian mempertahankan gaya bahasa (stilistik) dari Bsu, bukan struktur bahasa. Dari definisi dan penjelasan terakhir diperoleh pengertian bahwa penerjemahan dapat dilakukan secara tulis maupun lisan (alih bahasa). Namun satu hal utama yang harus diperhatikan dalam pengalihan pesan tersebut penerjemah harus mempertahankan pesan/amanat yang terdapat dalam Bsu dengan mereproduksi padanan alami terdekat dalam Bsa dan tetap mempertahankan gaya bahasa (language style) dalam mengungkapkan pesan tersebut ke dalam Bsa.

\section{Proses Penerjemahan}

Istilah penerjemahan sebenarnya mengacu pada tiga hal yaitu: 1) proses menerjemahkan (translating) yang terjadi dalam pikiran, kemudian 2) produk atau hasil terjemahan (translation), dan 3) konsep abstrak yang terkait kepada proses dan produk terjemahan. Sebagai proses, penerjemahan tidak terjadi secara serta merta begitu saja seperti yang terlihat - penerjemah membaca kemudian menulis terjemahannya - tetapi melibatkan proses batin/dalam pikiran sebelum akhirnya melahirkan produk/terjemahan (Bell, 1991:13).

Nababan (2003:25-28) dan Nida \& Taber (1982:33-34) mengambarkan bahwa proses penerjemahan terdiri dari tiga tahap, yaitu: 1) analisis, struktur permukaan (lahir) pesan dalam BSu dianalisis dari hubungan gramatikal dan makna kata dan kombinasi kata tersebut, dan 
Nababan menambahkan selain unsur linguistik tersebut, juga perlu analisis unsur ekstralinguistik, kemudian 2) pengalihan, materi makna yang telah diperoleh dialihkan dari Bsu ke Bsa di dalam pikiran penerjemah, terakhir, 3) restrukturisasi, pesan yang telah dialihkan dalam pikiran tersebut dibangun dan disusun ulang dengan lengkap dan dengan struktur yang berterima dalam bahasa sasaran.

Secara umum Nababan (2003) dan Nida \& Taber (1982) memiliki kesamaan pendapat mengenai tahap dalam proses penerjemahan, namun sebenarnya juga terdapat beberapa perbedaan diantara pendapat mereka. Pertama, Nababan (2003) menyatakan bahwa pada tahap kedua, penerjemah tidak hanya melakukan pengalihan dalam pikiran (batin), namun juga mengungkapkan isi dan pesan dalam Bsa secara lahir, sementara Nida \& Taber (1982) menganggap pengungkapan pesan secara lahir merupakan tahap ke tiga. Kemudian, Nida \& Taber menyatakan bahwa proses ini bukan linear sekali saja namun bisa berputar kembali untuk menghasilkan terjemahan yang benar-benar akurat (1982:34).

Sementara, menurut Nababan proses perubahan dan perbaikan itu terjadi pada tahap penyelarasan (restrukturisasi) berupa proses penyesuaian ragam dan gaya bahasa dengan jenis teks dan penyesuaian dengan target pembaca atau pendengar (2003:28). Berbeda dengan pendapat di atas, Larson (menggambarkan proses ini dengan tahapan yang lebih sederhana, diawali dari menemukan makna (discover the meaning), pada tahap ini penerjemah mempelajari dan menganalisis katakata, struktur gramatikal, situasi komunikasi, dan konteks budaya dari bahasa sumber untuk memahami maknanya. Setelah memahami makna Tsa tersebut, tahap berikutnya mengungkapkan kembali (re-express) makna tersebut dalam kata-kata dan struktur gramatikal yang tepat dalam Bsa. Larson tidak membedakan antara proses yang terjadi dalam pikiran (proses batin) dan proses lahir. Sehingga setelah memahami pesan/makna 
dari Tsa, penerjemah seakanakan langsung mengungkap ulang pesan tersebut dalam Bsa, sementara proses pengalihan yang terjadi dalam pikiran tidak digambarkan dan dijelaskan secara eksplisit (Larson, 1997:34).

Machali juga menyebutkan bahwa proses penerjemahan melewati tiga tahapan yaitu analisis Tsu, pengalihan, dan penyerasian yang dapat dilakukan secara berulang dan bolak balik agar hasil terjemahannya baik (Machali, 2000:33-39). Perbedaan yang terlihat jika dibandingkan dengan Nababan (2003) dan Larson (1984), Machali memandang proses ini dapat berlangsung bolak balik, penerjemah bisa kembali menganalisis walaupun telah berada pada tahap pengalihan jika hasil terjemahannya belum sempurna.

Kemudian, Suryawinata \& Hariyanto (2003:19-20) dengan menyempurnakan konsep yang digunakan Nida \& Taber (1982) mengajukan empat tahap dalam proses penerjemahan, yaitu:

1. Tahap analisis atau pemahaman, meliputi analisis gramatikal, makna tekstual dan kontekstual.

2. Tahap transfer, proses dalam pikiran berupa pengalihan makna dari Tsu.

3. Tahap restrukturisasi, proses pengungkapan makna dalam bentuk kata atau kalimat yang tepat dalam Bsa, dan

4. Tahap evaluasi dan revisi, tahap evaluasi ini, penerjemah mencocokkan kembali hasilnya dengan teks asli, jika masih kurang padan maka direvisi.

Dengan melihat pada tujuan penerjemahan sebagai faktor yang paling penting di dalam kegiatan penerjemahan, teori skopos menekankan pentingnya peranan penerjemah sebagai seorang pakar di dalam kegiatan penerjemahan dan semata-mata menawarkan informasi yang peranannya di dalam kegiatan harus diputuskan oleh penerjemah, tergantung pada harapan dan kebutuhan pembaca sasaran. Schaffner lebih lanjut 
mengatakan teori skopos sebagai bagian dari pendekatan fungsional memfokuskan pada penerjemah, memberikannya lebih banyak kebebasan dan pada saat yang sama juga lebih bertanggung jawab terhadap penerjemahannya. Oleh karena itu, penerjemah menjadi seorang pengarang teks bahasa sasaran yang bebas dari batasan-batasan yang ditentukan oleh konsep kesetiaan terhadap bahasa sumber itu sendiri (Schaffner, 1998:235-38).

Lebih lanjut Nord menyatakan bahwa penerjemah tidak selamanya dapat menentukan tujuan penerjemahan dari teks sumber ke bahasa sasaran dan oleh karena itu penerjemah memerlukan apa yang disebut dengan petunjuk penerjemahan (translation brief). Petunjuk penerjemahan akan memandu penerjemah terhadap informasi yang mereka pilih dari tawaran informasi awal (teks sumber) dan cara penerjemah mengemas informasi tersebut ke dalam teks sasaran. Menurut Nord, petunjuk penerjemahan tersebut terdiri dari fungsi teks yang diinginkan, pembaca teks sasaran, waktu dan tempat penerimaan teks, medium dimana teks tersebut akan diterjemahkan, dan alasan pemroduksian teks tersebut (Nord, 1991:60).

Bila petunjuk penerjemahan menyatakan bahwa fungsi atau tujuan harus diganti atau dipertahankan di dalam penerjemahan, penerjemah juga harus melakukan hal tersebut. Oleh karena itu, penerjemahan tidak lagi ditentukan oleh adanya prinsip kesepadanan (equivalence) tetapi berdasarkan kecukupan (adequacy) sesuai dengan petunjuk penerjemahan. Namun demikian, terjemahan tersebut harus masih bertalian secara logis atau masuk akal (coherent). Untuk menganalisis teks sumber yang berbeda dengan teks sasaran dan juga untuk melihat unsurunsur dalam teks sumber yang tetap dipertahankan dan yang harus diganti untuk menghasilkan teks sasaran yang fungsional dalam budaya sasaran, maka dibutuhkan apa yang disebut dengan faktor-faktor ekstratekstual dan 
faktor-faktor intratekstual. Faktor-faktor ekstratekstual dan intratekstual ini merupakan bagian dari teori skopos (Nord, 1991:35-43).

Faktor-faktor ekstratekstual merujuk pada situasi komunikasi dari teks sumber dan fungsi yang akan dihasilkan teks sasaran. Faktor-faktor ekstratekstual ini mengindikasikan fungsi-fungsi teks yang ingin dicapai yang mencakup informasi mengenai penulis atau pengirim teks (who), penerima teks yang dimaksud (to whom), maksud pengirim (what for), medium atau kanal tempat teks dikomunikasikan, tempat dan waktu komunikasi produksi teks dan penerima teks, dan motif komunikasi (why). Faktor-faktor ekstratekstual dapat diidentifikasi sebelum membaca teks.

Machali berpendapat bahwa Istilah penerjemah sudah tidak asing lagi bagi kita. Secara umum kita mengetahui bahwa pernerjemah adalah sebuah profesi seseorang ketika mereka menerjemahkan atau mengalihkan satu bahasa ke bahasa lain baik dalam bentuk lisan (interpreter) maupun tulisan (translator). Namun ketika kita bertanya langsung kepada para penerjemah maka jawaban yang sering terdengar adalah mereka tidak pernah dengan sengaja memilih penerjemah sebagai profesi, sebagaimana diakuinya profesi guru dan tukang batu (Machali, 2000:1). Ini adalah salah satu contoh kasus saja. Secara umum, Machali menambahkan bahwa penerjemah dapat digolongkan menjadi tiga golongan: penerjemah yang bekerja di perusahaan, penerjemah paruh waktu, dan penerjemah bebas (Machali, 2000:2).

\section{Syarat penerjemah yang baik}

Untuk menghasilkan suatu terjemahan, seorang penerjemah tidak serta merta menerjemahkan satu bahasa ke bahasa yang lain tetapi harus memperhatikan berbagai hal agar hasil terjemahan tersebut bisa diterima dan tidak merubah pesan serta makna yang dimaksud oleh bahasa sumber atau bahasa asal. Karena pada dasarnya penerjemahan merupakan cara 
untuk mencari padanan (equivalent) kata atau kalimat yang akan diterjemahkan. Penerjemah juga harus bisa menangkap makna konseptual suatu istilah dalam bahasa sumber, jika tidak bisa menganalogikan dengan benar maka akan menimbulkan kesalahpahaman. Nababan (2003:9), berpendapat bahwa tidaklah berlebihan terjemahan yang tidak baik akan menyesatkan dan meracuni pembaca. Selain itu dalam Translation, menurut Catford menyatakan bahwa harus ada padanan materi tekstual dan ditambahkan juga bahwa masalah utama dalam penerjemahan adalah bagaimana menemukan padanan terjemahan di dalam bahasa sasaran. Hal ini menandakan bahwa padanan tersebut sudah mengacu pada keseluruhan bahasa sasaran tidak hanya materi tekstual saja (Suryawinata, 2003:13).

\section{Penerjemahan dan Terjemahan}

Sering kita mendengar istilah penerjemahan, jasa penerjemahan, ataupun kriteria penerjemahan. Di sisi lain kita juga mendengar istilah terjemahan. Lalu apa yang membedakan kedua istilah tersebut (penerjemahan dan terjemahan)? Menurut T.Bell, penerjemahan diartikan sebagai proses dan produk. Karena suatu penerjemahan difokuskan pada suatu persyaratan bahwa isi dan style bahasa sumber harus sesuai ketika dialihkan ke bahasa sasaran atau harus ada unsur equivalence. Dalam bukunya disebutkan process and result untuk membedakan antara penerjemahan dan terjemahan, T.Bell menulis (1991:13):

The process or result of converting information from one language or language variety into another... the aim is to reproduce as accurately as possible all grammatical and lexical features of the "source language" original by finding equivalents in the "target language". At the same time all factual information contained in the original text...must be retained in the translation. 
Selain itu, T.Bell juga menyatakan bahwa terjemahan merupakan produk/hasil dari proses penerjemahan. Menurut Nababan proses (penerjemahan) ialah serangkaian kegiatan yang dilakukan dengan sengaja. Proses penerjemahan dapat diartikan pula sebagai serangkaian kegiatan yang dilakukan oleh seorang penerjemah pada saat dia mengalihkan amanat dari bahasa sumber ke bahasa sasaran. Tentu saja pengalihan amanat ini juga harus didasari oleh berbagai kemampuan yang wajib dimiliki oleh seorang penerjemah, misalnya kebahasaan, penguasaan tehnik, teori, penggunaan sarana pembantu, dan lain-lain. Karena jika seorang penerjemah dalam proses penerjemahan tidak memperhatikan syarat-syarat yang harus dimiliki seorang penerjemah maka bisa saja hasil penerjemahan (teks terjemahan) akan menyesatkan pembaca atau pengguna. Selanjutnya, Nababan menambahkan bahwa tidaklah berlebihan kalau ada pendapat yang menyatakan bahwa terjemahan yang tidak baik akan menyesatkan dan sekaligus meracuni pembaca (Nababan, 2003:24).

\section{Penelitian Terjemahan}

Kadang-kadang suatu konsep atau teori dalam hal ini tentang penerjemahan dapat dengan mudah dipahami dan dikuasai, namun pada prakteknya atau pada saat proses penerjemahan tersebut berlangsung, seorang penerjemah terkadang mengalami kesulitan dalam pengaplikasiannya. Maka proses dan hasil terjemahan tersebut bisa diteliti. Menurut Newmark menyatakan bahwa kadangkala suatu konsep bisa dengan mudah dideskripsikan dalam uraian atau teori. Akan tetapi, bila sudah berada dalam tataran praktek, mungkin sekali konsep-konsep ini sulit dibedakan atau bahkan dikenali secara jelas. Dalam konteks ini penelitian yang dilakukan bisa berupa pencarian proses penerjemahan 
yang dilakukan seorang penerjemah apakah sudah linier atau bahkan tidak teratur (Newmark, 1988:84).

Suryawinata menambahkan bahwa selain penelitian tentang proses dan hasil terjemahan, masih ada dua hal lagi yang bisa diteliti yaitu (1) penelitian tentang pengajaran terjemahan, dan (2) penelitian yang menggunakan terjemahan sebagai alatnya. Sedangkan pendekatan yang dibutuhkan dalam penelitian tentang terjemahan adalah kualitatif dan kuantitatif, tergantung pada tujuan penelitiannya. Apabila ingin mencari korelasi antara pengalaman penerjemahan seorang penerjemah dengan kualitas atau jenis kesalahan penerjemahan, maka dibutuhkan metode kuantitatif. Selain itu, metode ini juga sangat tepat digunakan dalam penelitian dalam lingkup pengajaran terjemahan, misalnya dari sisi mahasiswa, tingkat kecerdasan mereka terhadap kualitas atau kesalahan terjemahan. Sedangkan metode berikutnya digunakan apabila penelitian tersebut berisi tentang kesalahan penerjemahan, prosedur dan lain-lain, maka lebih tepat digunakan metode kualitatif (Suryawinata, 2003:171).

Untuk melakukan sebuah penelitian tentang penerjemahan seseorang harus terlebih dahulu menguasai tentang, bahasa sumbar dan bahasa sasaran, teori penerjemahan, dan bidang ilmu yang diterjemahkan. Jadi mereka bisa saja: (a) agen penerjemahan yang ingin meneliti kualitas dari hasil terjemahan, (b) penerbit karya terjemahan, misalnya ingin meneliti karya-karya terbitannya, (c) klien terjemahan, (d) kritikus, ilmuan atau pemerhati masalah terjemahan dalam hal ini bisa dosen, mahasiswa ataupun peneliti (Suryawinata, 2003:179).

Sementara disisi lain, dalam konteks penerjemahan, keterpahaman ini berkaitan dengan kualitas terjemahan. Kualitas ini dapat bersifat intrinsik, yaitu bertalian dengan ketepatan, kejelasan, dan kewajaran nas. Namun, dapat pula bersifat ekstrinsik, yaitu berkenaan dengan tanggapan pembaca dan pemahamannya terhadap terjemahan. Kualitas tersebut 
dapat diketahui dengan beberapa teknik evaluasi. Nida dan Taber menyatakan bahwa kualitas terjemahan dapat diukur dengan (a) menggunakan teknik rumpang, (b) meminta tanggapan pembaca terhadap nas terjemahan, (c) mengetahui reaksi para penyimak terhadap pembacaan nas terjemahan, dan (d) membaca terjemahan dengan nyaring, sehingga dapat diketahui apakah pembacaannya itu lancar atau tersendat-sendat (Nida, 1982:168-173).

Berbeda halnya dengan Larson yang membicarakan tentang kualitas terjemahan dari empat aspek, yaitu (a) alasan dilakukannya penilaian, (b) orang yang menilai, (c) cara melakukan penilaian, dan (d) pemanfaatan hasil penilaian. Penilaian dilakukan untuk mengetahui ketepatan, kejelasan, dan kewajaran terjemahan. Pekerjaan ini dapat dilakukan oleh penerjemah sendiri, penilai khusus, konsultan, dan peninjau. Keempat pihak ini dapat menilai kualitas terjemahan dengan (a) membandingkan terjemahan dengan nas sumber, (b) menerjemahkan kembali nas sumber, (c) menilai keterpahaman terjemahan, (d) mengukur keterbacaan nas, dan (e) menilai konsistensi terjemahan (Larson, 1984:485-503).

Menurut Emzir (2015:247), kualitas merupakan sentral dalam bidang penerjemahan dan interpretasi, baik pada tingkat pemerolehan awal sebagai penilaian formatif dalam program pendidikan maupun pada tingkat pengembangan instrument untuk sertifikasi professional, serta dalam mengatur kualitas terjemahan/interpretasi untuk instrument dan proses yang digunakan untuk tujuan penilaian.

\section{Parameter Terjemahan Yang Berkualitas}

Terjemahan yang berkualitas harus memenuhi tiga aspek, yaitu aspek keakuratan, aspek keberterimaan dan aspek keterbacaan. Ketiga aspek tersebut diuraikan di bawah ini. 


\subsection{Aspek Keakuratan}

Keakuratan merupakan sebuah istilah yang digunakan dalam pengevaluasian terjemahan untuk merujuk pada apakah teks bahasa sumber dan teks bahasa sasaran sudah sepadan ataukah belum. Konsep kesepadanan mengarah pada kesamaan isi atau pesan antar keduanya. Suatu teks dapat disebut sebagai suatu terjemahan, jika teks tersebut mempunyai makna atau pesan yang sama dengan teks lainnya (baca: teks bahasa sumber). Oleh sebab itu, usaha-usaha untuk mengurangi atau menambahi isi atau pesan teks bahasa sumber dalam teks bahasa sasaran harus dihindari.

Usaha-usaha yang seperti berarti menghianati penulis asli teks bahasa sumber dan sekaligus membohongi pembaca sasaran. Dalam konteks yang lebih luas, pengurangan atau penambahan dapat menimbulkan akibat yang fatal pada manusia yang menggunakan suatu karya terjemahan, terutama pada teks-teks terjemahan yang beresiko tinggi, seperti teks terjemahan di bidang hukum, kedokteran, agama dan teknik.

Di dalam literatur teori penerjemahan terdapat beberapa teknik penerjemahan yang dapat dimanfaatkan untuk mengatasi masalah padanan. Dua di antaranya adalah penghilangan (deletion) dan penambahan (addition). Kedua teknik penerjemahan itu bukan dimaksudkan untuk mengurangi informasi atau menambahi informasi sesuka hati, tetapi dimaksudkan untuk menghasilkan terjemahan yang berterima dan mudah dipahami oleh pembaca sasaran. Dalam praktik penerjemahan yang sesungguhnya, teknik penambahan ditujukan untuk mengeksplisitkan atau untuk memperjelas suatu konsep bahasa sumber terutama jika konsep tersebut tidak mempunyai one-to-one correspondence dalam bahasa sasaran. 


\subsection{Aspek Keberterimaan}

Aspek kedua dari terjemahan yang berkualitas terkait dengan masalah keberterimaan. Istilah keberterimaan merujuk pada apakah suatu terjemahan sudah diungkapkan sesuai dengan kaidah-kaidah, norma dan budaya yang berlaku dalam bahasa sasaran atau kah belum, baik pada tataran mikro maupun pada tataran makro. Konsep keberterimaan ini menjadi sangat penting karena meskipun suatu terjemahan sudah akurat dari segi isi atau pesannya, terjemahan tersebut akan ditolak oleh pembaca sasaran jika cara pengungkapannya bertentangan dengan kaidah-kaidah, norma dan budaya bahasa sasaran.

\subsection{Aspek Keterbacaan}

Pada mulanya istilah keterbacaan hanya dikaitkan dengan kegiatan membaca. Kemudian, istilah keterbacaan itu digunakan pula dalam bidang penerjemahan karena setiap kegiatan menerjemahkan tidak bisa lepas dari kegiatan membaca. Dalam konteks penerjemahan, istilah keterbacaan itu pada dasarnya tidak hanya menyangkut keterbacaan teks bahasa sumber tetapi juga keterbacaan teks bahasa sasaran. Hal itu sesuai dengan hakekat dari setiap proses penerjemahan yang memang selalu melibatkan kedua bahasa itu sekaligus. Akan tetapi, hingga saat ini indicator yang digunakan untuk mengukur tingkat keterbacan suatu teks masih perlu dipertanyakan keandalannya. Bahkan, Gilmore dan Root (1977:102) berpendapat bahwa ukuran suatu teks yang didasarkan pada faktor-faktor kebahasaan dan pesonainsani tidak lebih dari sekedar alat bantu bagi seorang penulis dalam menyesuaikan tingkat keterbacaan teks dengan kemampuan para pembaca teks itu.

\section{Bidang Penilaian Terjemahan}


Penilaian terhadap kualitas terjemahan sangat relevan diterapkan pada empat bidang, yaitu pada 1) bidang terjemahan yang dipublikasian, 2) bidang terjemahan profesional, 3) bidang terjemahan yang dihasilkan dalam konteks pengajaran mata kuliah praktik penerjemahan dan 4) bidang terjemahan yang dikaji dalam konteks penelitian penerjemahan. Pada hakikatnya, terjemahan yang dipublikasikan identik dengan terjemahan professional karena keduanya dihasilkan oleh penerjemah profesional. Perbedaannya adalah bahwa terjemahan yang dipublikasikan dibaca oleh kalangan luas dan terjemahan professional dibaca oleh kalangan terbatas. Terjemahan dalam konteks pengajaran merujuk pada terjemahan yang dihasilkan oleh anak didik pada perkuliahan praktik penerjemahan.

Penelitian yang relevan terkait dengan penelitian ini adalah penelitian yang dilakukan oleh Syihabuddin (Hal. 1) Program Studi Bahasa Arab, FPBS Universitas Pendidikan Indonesia yang berjudul "Studi Tentang Kualitas Terjemahan dan Implikasinya Terhadap Pengajaran Penerjemah" dan oleh Winantu Kurnianingtyas S.A yang berjudul "Kualitas Hasil Penerjemahan Individu \& Penerjemahan Kelompok: Studi kasus proses dan hasil penerjemahan mahasiswa PPS Prodi Linguistik minat utama penerjemahan UNS". (Winantu: Hal. 1).

\section{B. TUJUAN PENELITIAN}

Berdasarkan pada latar belakang tersebut, maka penelitian ini bertujuan: 1) untuk mengetahui dan mengkaji kualitas hasil penerjemahan kelompok mahasiswa S2 UNM-Malang (Studi Kasus Hasil Penerjemahan Buku Teks -Approaches to Discoursell yang di tulis oleh Deborah Schiffrin). 2). Untuk mengetahui kesalahan gramatika dan kesepadanan atau kaidah tata bahasa Indonesia hasil penerjemahan kelompok mahasiswa S2 unm-malang (studi kasus hasil penerjemahan buku teks -approaches to discoursell yang di tulis oleh Deborah Schiffrin. 


\section{METODE PENELITIAN}

Penelitian ini menggunakan metode deskripsi kualitatif dan merupakan penelitian yang mengarah pada jenis kebijakan tertentu yang menjadi alternatif model untuk menilai kualitas terjemahan di Indonesia. Dalam studi kebijakan ini peneliti harus bisa menemukan dan merumuskan baik kekuatan maupun kelemahan suatu kondisi atau lokasi tertentu dengan kebutuhan khususnya, sehingga bisa diusulkan kebijakan yang paling tepat berdasarkan kondisi dan kekhususan karakteristiknya (Sutopo, 2002: 117). Kebijakan baru inilah yang akan menjadi alternatif model untuk menilai kualitas terjemahan di Indonesia.

Dalam penelitian ini, masalah utamanya adalah penilaian kualitas terjemahan dari bahasa Inggris ke dalam bahasa Indonesia. Sumber data merupakan bagian yang sangat penting dalam penelitian kualitatif karena ketepatan memilih dan menentukan jenis sumber data menentukan ketepatan dan kekayaan data atau informasi yang diperoleh.

Data diperoleh melalui buku sumber dan sasaran $\|$ Approaches to Discoursell karangan Deborah Schiffrin dan diterjemahkan oleh 23 penerjemah (Mahasiswa S2 PPs Uiversitas Negeri Malang), dan satu editor antara lain: -Unang, Suntari, Majid, Marheny, Laili, Endang, Kawit, Rasani, Matrawi, Nur, Rajab, Nisa, Wiwik, Tatik, Basith, Sujak, Razak, Cicik, Nardi, Hardji, Hadi, Ary, dan Nopiah, Editor: Prof. Dr. Abd. Syukur Ibrahimll. Pengumpulan data dalam penelitian kualitatif secara umum dapat dikelompokkan ke dalam dua cara, yaitu metode noninteraktif dan interaktif. Sutopo (1996: 55) menyatakan, metode interaktif meliputi pencatatan dokumen atau arsip (content analysis) dan kuesioner, sedangkan metode interaktif meliputi wawancara mendalam (in-depth interviewing).

Data tidak dapat diperoleh tanpa adanya sumber data. Sumber data dalam penelitian kualitatif dapat berupa manusia, peristiwa dan tingkah 
laku, dokumen dan arsip, serta berbagai benda lain (Sutopo, 2002: 50 53). Sumber data penelitian ini berupa 1) manusia, yaitu penerjemah, mahasiswa, dosen dan pakar penerjemahan, dan stakeholders dan 2) literatur-literatur baik dalam bentuk buku, artikel ilmiah maupun laporan yang memuat masalah penilaian kualitas terjemahan. Teknik sampling yang dipakai adalah purposive sampling. Seperti yang ditegaskan oleh Sutopo (2002: 36), teknik cuplikan penelitian kualitatif cenderung bersifat purposive karena dipandang lebih mampu menangkap kelengkapan dan kedalaman data. Data penelitian ini dikumpulkan melalui teknik simak dan catat, sementara untuk wawancara mendalam dan Focus Group Discussion tidak dilakukan mengingat adanya keterbatasan waktu penelitian. Teknik simak dan catat ini digunakan untuk mengumpulkan data tentang orientasi dan kekuatan serta kelemahan dari strategi-strategi penilaian kualitas yang sudah ada. Terjemahan teks buku. Kekuatan dan kelemahan yang dimaksudkan terkait dengan kemampuan dari masingmasing strategi penilaian kualitas terjemahan tersebut dalam mengukur kualitas terjemahan, baik dari segi tingkat keakuratan pesan, tingkat keberterimaan dan tingkat keterbacaan suatu terjemahan.

\section{INSTRUMEN PENILAIAN KUALITAS TERJEMAHAN}

Instrumen penilaian kualitas terjemahan meliputi: 1) instrumen penilai tingkat keakuratan pesan, 2) instrumen penilai tingkat keberterimaan terjemahan, dan 3) instrumen penilai tingkat keterbacaan terjemahan. Masing-masing dari instrumen penilai kualitas terjemahan terdiri atas tiga bagian. Bagian pertama menunjukkan kategori terjemahan. Bagian kedua merupakan skor atau angka dengan skala 1 sampai dengan 3 , yang diurutkan menurut piramida terbalik yaitu semakin berkualitas suatu terjemahan, semakin skor atau angka yang diperolehnya dan demikian 
pula sebaliknya. Bagian ketiga merupakan parameter kualitatif dari masingmasing kategori terjemahan. Ketiga instrumen itu disajikan di bawah ini.

Tabel Instrumen Penilai Keakuratan Terjemahan

\begin{tabular}{|c|c|c|}
\hline $\begin{array}{l}\text { Kategori } \\
\text { Terjemahan }\end{array}$ & Skor & Parameter Kualitatif \\
\hline Akurat & 3 & $\begin{array}{l}\text { Makna kata, istilah teknis, frasa, klausa, kal } \\
\text { atau teks bahasa sumber dialihkan secara akura } \\
\text { dalam bahasa sasaran; sama sekali tidak te } \\
\text { distorsi makna. }\end{array}$ \\
\hline Berterima & 3 & $\begin{array}{l}\text { Terjemahan terasa alamiah; istilah teknis } \\
\text { igunakan lazim digunakan dan akrab } \\
\text { pembaca; frasa, klausa dan kalimat yang digun } \\
\text { sudah sesuai dengan kaidah-kaidah ba } \\
\text { Indonesia. }\end{array}$ \\
\hline Tingkat Keterbacaan Tinggi & 3 & $\begin{array}{l}\text { Kata, istilah teknis, frasa, klausa, kalimat atau } \\
\text { terjemahan dapat dipahami dengan mudah } \\
\text { pembaca. }\end{array}$ \\
\hline Kurang Akurat & 2 & $\begin{array}{l}\text { Sebagian besar makna kata, istilah teknis, fi } \\
\text { klausa, kalimat atau teks bahasa sumber st } \\
\text { dialihkan secara akurat ke dalam bahasa sasa } \\
\text { Namun, masih terdapat distorsi makna } \\
\text { terjemahan makna ganda (taksa) atau ada ma } \\
\text { yang dihilangkan, yang mengganggu keut } \\
\text { pesan. }\end{array}$ \\
\hline Kurang Berterima & 2 & $\begin{array}{l}\text { Pada umumnya terjemahan sudah terasa alan } \\
\text { namun ada sedikit masalah pada penggunaan is } \\
\text { teknis atau terjadi sedikit kesalahan gramatikal. }\end{array}$ \\
\hline Tingkat Keterbacaan Sedang & 2 & $\begin{array}{l}\text { Pada umumnya terjemahan dapat dipahami } \\
\text { pembaca; namun ada bagian tertentu yang h } \\
\text { dibaca lebih dari satu kali untuk memah } \\
\text { terjemahan. }\end{array}$ \\
\hline Tidak Akurat & 1 & $\begin{array}{l}\text { Makna kata, istilah teknis, frasa, klausa, kal } \\
\text { atau teks bahasa sumber dialihkan secara t }\end{array}$ \\
\hline
\end{tabular}




\begin{tabular}{|c|c|c|}
\hline & & $\begin{array}{l}\text { akurat ke dalam bahasa sasaran atau dihilang } \\
\text { (deleted). }\end{array}$ \\
\hline Tidak Berterima & 1 & $\begin{array}{l}\text { Terjemahan tidak alamiah atau terasa seperti k } \\
\text { terjemahan; istilah teknis yang digunakan t } \\
\text { lazim digunakan dan tidak akrab bagi pemb } \\
\text { frasa, klausa dan kalimat yang digunakan t } \\
\text { sesuai dengan kaidah-kaidah bahasa Indonesia. }\end{array}$ \\
\hline Tingkat Keterbacaan Rendah & 1 & Terjemahan sulit dipahami oleh pembaca \\
\hline
\end{tabular}

\section{E. HASIL PENELITIAN}

Berikut adalah beberapa hasil penilaian kualitas terjemahan dengan menggunakan instrument penilaian yang tujuannya adalah untuk memberikan gambaran yang jelas tentang cara model penilaian kualitas terjemahan tersebut diterapkan. Penilaian kualitas merupakan suatu terjemahan yang dilakukan oleh satu orang penilai untuk masing-masing tingkat keakuratan, keberterimaan dan keterbacaan teks terjemahan. Dalam penelitian ini, di paparkan beberapa contoh hasil terjemahan yang terdapat didalam buku Approaches to Discourse yang di tulis oleh Deborah Schiffrin.

\begin{tabular}{|c|l|l|l|c|c|}
\hline \multirow{2}{*}{$\begin{array}{c}\text { N } \\
\text { o }\end{array}$} & $\begin{array}{l}\text { Bahasa } \\
\text { Sumber }\end{array}$ & $\begin{array}{l}\text { Bahasa } \\
\text { Sasaran }\end{array}$ & $\begin{array}{l}\text { Keakurata } \\
\text { n }\end{array}$ & $\begin{array}{c}\text { Keberterimaa } \\
\mathbf{n}\end{array}$ & $\begin{array}{c}\text { Keterbacaa } \\
\mathbf{n}\end{array}$ \\
\hline 1 & $\begin{array}{l}\text { At the same } \\
\text { time that we } \\
\text { need to stress } \\
\text { social }\end{array}$ & $\begin{array}{l}\text { Manakala } \\
\text { yang kami } \\
\text { butuh } \\
\text { menekankan }\end{array}$ & 1 & 2 & 2 \\
\hline
\end{tabular}




\begin{tabular}{|c|c|c|c|c|c|}
\hline 2 & $\begin{array}{l}\text { scientific } \\
\text { notions of } \\
\text { realibility and } \\
\text { validity, it is } \\
\text { also important } \\
\text { to note the } \\
\text { inherent } \\
\text { futility (and to } \\
\text { some } \\
\text { scholars, the } \\
\text { foolhardiness) } \\
\text { of trying to } \\
\text { assign an } \\
\text { understanding } \\
\text { or function to } \\
\text { an utterance } \\
\text { with which all } \\
\text { would agree. } \\
P \text {. } 88 .\end{array}$ & $\begin{array}{l}\text { ungkapan } \\
\text { reliabilitas } \\
\text { dan validitas } \\
\text { ilmu social, } \\
\text { hal ini juga } \\
\text { penting } \\
\text { untuk } \\
\text { mencatat } \\
\text { lekatnya } \\
\text { kegagalan } \\
\text { (dan untuk } \\
\text { beberapa } \\
\text { ilmuwan, } \\
\text { kengawuran) } \\
\text { mencoba } \\
\text { untuk } \\
\text { memberikan } \\
\text { pengertian } \\
\text { atau fungsi } \\
\text { kearah } \\
\text { tuturan } \\
\text { dengan yang } \\
\text { semua orang } \\
\text { setuju. } \\
\text { Hal. } 144 \text {. } \\
\text { Maka secara } \\
\text { lebih jauh, } \\
\text { saya } \\
\text { menyarankan } \\
\text { bahwa dia } \\
\text { sedang } \\
\text { dietnya Zelda } \\
\text { mengajukan } \\
\text { sebuah } \\
\text { pengajaran } \\
\text { interaksional } \\
\text { yang lebih } \\
\text { bertipe } \\
\text { pernyataan } \\
\text { dikemukakan } \\
\text { lehnita }\end{array}$ & 2 & 2 & 2 \\
\hline
\end{tabular}




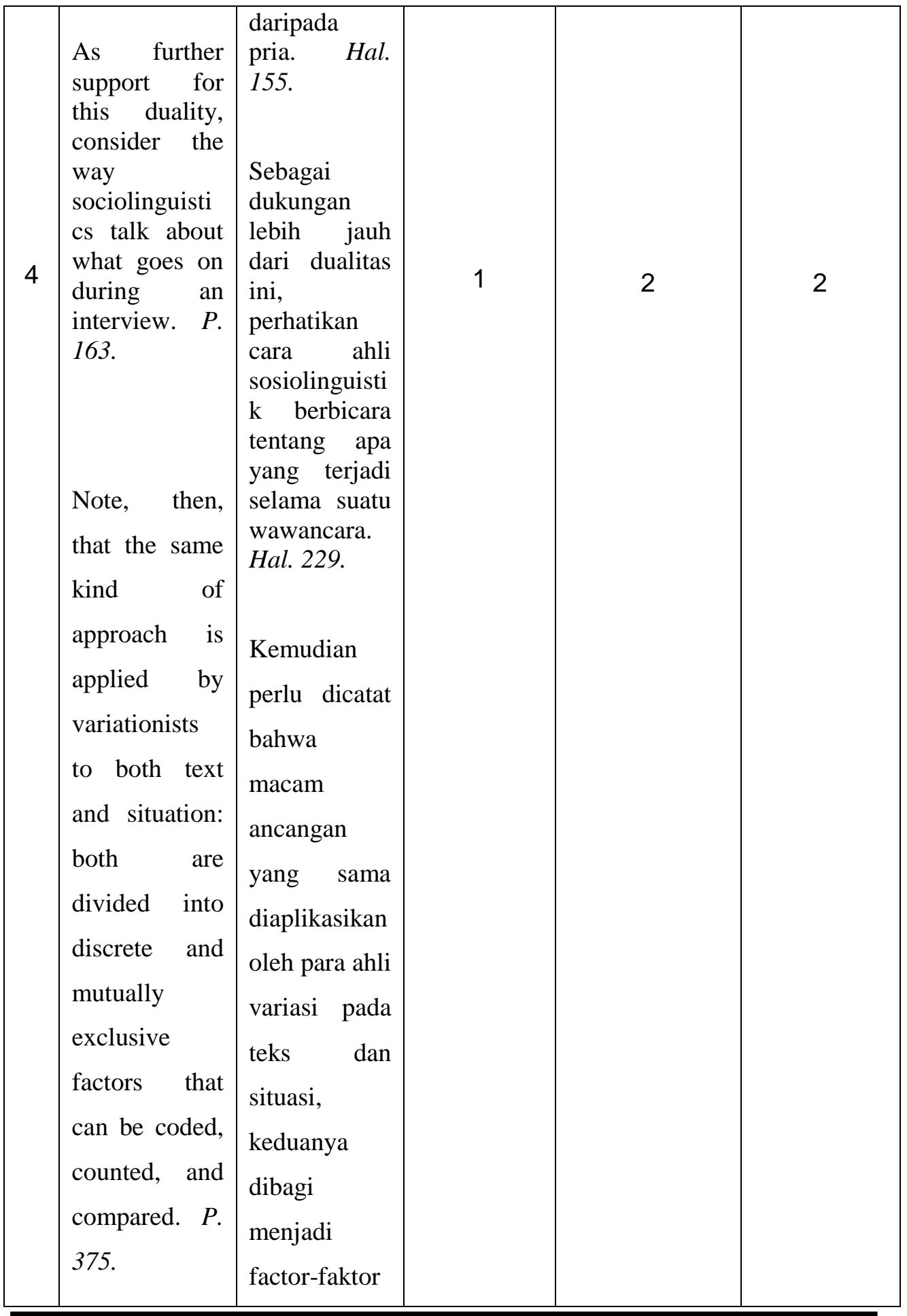




\begin{tabular}{|l|l|l|l|l|}
\hline & $\begin{array}{l}\text { terpisah dan } \\
\text { timbal balik } \\
\text { secara } \\
\text { terpisah juga } \\
\text { yang dapat } \\
\text { diartikan, } \\
\text { dihitung, dan } \\
\text { dibandingkan }\end{array}$ & & & \\
. Hal. 566. & & & \\
\hline
\end{tabular}

\section{F. PEMBAHASAN}

Kalimat sumber 1 sudah diterjemahkan ke dalam bahasa sasaran, tetapi masih belum sempurna. Kalimat terjemahannya belum memenuhi kaidah tatabahasa baku bahasa Indonesia dan pembaca sasaran tidak dapat memhami kalimat terjemahan tersebut dengan mudah. Selain kalimat sederhana tersebut, ada juga beberapa data sumber yang berwujud kalimat kompleks. sehingga dari teknik-teknik penerjemahan yang digunakan, terjemahannya dalam bahasa sasaran belum akurat akurat. Untuk kalimat berikut:

At the same time that we need to stress social scientific notions of realibility and validity, it is also important to note the inherent futility (and to some scholars, the foolhardiness) of trying to assign an understanding or function to an utterance with which all would agree. (Manakala yang kami butuh menekankan ungkapan reliabilitas dan validitas ilmu social, hal ini juga penting untuk mencatat lekatnya kegagalan (dan untuk beberapa ilmuwan, kengawuran) mencoba untuk memberikan pengertian atau fungsi kea rah tuturan dengan yang semua orang setuju).

Sebaiknya diterjemahkan sebagai berikut: 
"Pada saat yang sama, bahwa kita perlu menekankan gagasan ilmiah mengenai realibility dan validitas ilmu sosial, hal itu juga penting agar dicatat sebagai kesia-siaan yang melekat (dan sebagian sarjana, kenekatan yang) berusaha untuk menetapkan pemahaman atau fungsi sebuah tuturan dimana semua akan setuju."

Untuk kalimat sumber 2, 3,dan 4 juga belum sesuai dengan standar bahasa Indonesia yang baku, sehingga aspek keakuratan, keberterimaan dan keterbacaan menjadi kurang maksimal.

Kalimat kedua:

Thus far, I have suggested that Zelda's She"s on a diet proposes and interactional alignment that is more typical of the stances taken by women than those taken by men. (Maka secara lebih jauh, saya menyarankan bahwa dia sedang dietnya Zelda mengajukan sebuah pengajaran interaksional yang lebih bertipe pernyataan yang dikemukakan oleh wnita daripada pria).

Sebaiknya diterjemahkan sebagai berikut:

"Sejauh ini, saya telah menyarankan bahwa pada dietnya Zelda mengusulkan dan keselarasan interaksional yang lebih khas dari sikap yang diambil oleh wanita daripada yang diambil oleh pria".

Kalimat ketiga:

As further support for this duality, consider the way sociolinguistics talk about what goes on during an interview. (Sebagai dukungan lebih jauh dari dualitas ini, perhatikan cara ahli sosiolinguistik berbicara tentang apa yang terjadi selama suatu wawancara).

Sebaiknya diterjemahkan sebagai berikut:

Sebagai dukungan lebih lanjut untuk dualitas ini , pertimbangkan cara sosiolinguistik berbicara tentang apa yang terjadi selama wawancara".

Kalimat keempat:

Note, then, that the same kind of approach is applied by variationists to both text and situation: both are divided into discrete and mutually exclusive 
factors that can be coded, counted, and compared. (Kemudian perlu dicatat bahwa macam ancangan yang sama diaplikasikan oleh para ahli variasi pada teks dan situasi, keduanya dibagi menjadi factor-faktor terpisah dan timbal balik secara terpisah juga yang dapat diartikan, dihitung, dan dibandingkan).

Sebaiknya diterjemahkan sebagai berikut:

Catatan, kemudian, bahwa jenis yang sama dari pendekatan yang diterapkan oleh ahli variasi untuk teks dan situasi: keduanya dibagi menjadi faktor diskrit dan saling eksklusif yang dapat dikodekan, dihitung, dan dibandingkan.

\section{G. KETERBATASAN PENELITIAN}

Dalam penelitian ini, peneliti hanya melihat keterbatasan aspek kualitas terjemahan dari bahasa sumber ke bahasa sasaran khususnya yang terkait dengan unsur keakuratan, keberterimaan dan keterbacaan saja. Sehingga, dalam penelitian lebih lanjjut dapat mencari temuan baru baik dari aspek kesepadanan, pergeseran maupun kesalahan gramatika.

\section{H. SIMPULAN DAN SARAN}

\section{Simpulan}

Untuk menghasilkan suatu terjemahan, seorang penerjemah tidak serta merta menerjemahkan satu bahasa ke bahasa yang lain tetapi harus memperhatikan berbagai hal agar hasil terjemahan tersebut bisa diterima dan tidak merubah pesan serta makna yang dimaksud oleh bahasa sumber atau bahasa asal. Karena pada dasarnya penerjemahan merupakan cara untuk mencari padanan (equivalent) kata atau kalimat yang akan diterjemahkan. Hasil penelitian menunjukan bahwa kualitas hasil terjemahan masih belum maksimal sehingga aspek keakuratan, 
keberterimaan dan keterbacaan relative sedikit atau bahkan tidak digunakan sebagai rujukan.

\section{Saran}

Untuk pengembangan dan perbaikan kualitas hasil terjemahan, peneliti menyarankan agar kedepan dapat dilakukan perbaikan atau edisi refisi terjemahan agar dapat dimanfaatkan oleh mahasiswa pendidikan bahasa atau linguistic sebagai bahan rujukan.

\section{REFERENSI}

Basil Hatim. 2001. Teaching and Researching Translation. London : Pearson Education.

Bassnett-McGuire, Susan. 1991. Translation Studies. London: Routledge. Bell, R.T. 1991. 1991. Translation and Translating: Theory and Practice. London: Longman.

Catford, J. 1980. A Linguistic Theory of Translation. Oxford: Oxford University Press.

Emzir. 2015. Teori dan Pengajaran Penerjemahan. Depok : Rajagrafindo.

J. C. Catford. 1965. A Linguistic Theory of Translation. London: Oxford University Press.

Kridalaksana, H. 2008. Kamus Linguistik. Jakarta: PT Gramedia Pustaka Utama.

Larson, M.L. 1997. Meaning Based Translation 2nd Edition. New York: University Press of America.

1984. Meaning-Based Translation: A Guide to Crass-Language Equivalence. Boston: University Press of America.

Machali, R. 2000. Pedoman Bagi Penerjemah. Jakarta: Gramedia Widiasarana Indonesia.

Newmark, Peter. 1988. A Textbook of Translation. London: Prentice Hall. 
1988. Approaches to Translation. Oxford: Pergamon Press.

Nida, E.A dan Taber, C. 1982. The Theory and Practice of Translation. Leiden: E.J. Brill.

Nababan, M.R. 2003. Teori Menerjemah Bahasa Inggris. Yogyakarta: Pustaka Pelajar.

Nord, Christiane. 1991/97. Text Analysis in Translation. Theory, Methodology, and Dicdactic Application of a Model for TranslationOriented Text Analysis. Amsterdam: Rodopi B.V.

Nida, E.A. and Taber, C. 1982. The Theory and Practise of Translation. Leiden: The United Bible Societies.

Nababan,M.Rudolf. 2003. Teori Menerjemah Bahasa Inggris. Pustaka Pelajar:Yogyakarta.

Pinchuck, I. 1977. Scientific and Technical Translation. London: Andre Deutsch.

Savory, T. 1969. The Art of Translation. London: Jonathan Cape.

Suryawinata, Z. dan Hariyanto, S. 2003. Translation "Bahasan Teori \& Penuntun Praktis Menerjemahkan”. Yogyakarta: Kanisius.

Schaffner. Skopos Theory. 1998b. In Mona Baker (ed.) Routledge Encyclopedia of Translation Studies. London: Routledge.

Suryawinata, Zuchridin, Sugeng Hariyanto. 2003. Translation: Bahasan Teori dan Penuntun Praktis Menejemahkan. Yogyakarta: Penerbit Kanisius.

Sakri, A. 1995. Bangun Kalimat Bahasa Indonesia. Bandung: Penerbit ITB.

Syihabuddin. Studi Tentang Kualitas Terjemahan dan Implikasinya Terhadap Pengajaran Penerjemah. Bandung: Program Studi Bahasa Arab, FPBS Universitas Pendidikan Indonesia.

Sutopo, H. B. 1996. Metodologi Penelitian Kualitatif: Metodologi untuk IImuIImu Sosial dan Budaya. Surakarta: Sebelas Maet University Press. 
T. Bell, Rodger. 1991. Translation and Translating: Theory and Practic. Longman: London.

Winantu Kurnianingtyas S.A. Kualitas Hasil Penerjemahan Individu \& Penerjemahan elompok: Studi kasus proses dan hasil penerjemahan mahasiswa. Solo: PPS Prodi Linguistik minat utama penerjemahan UNS. 